\title{
Professional changes of primary science teachers: experience on collaborative action research in Thailand
}

Sirinapa Kijkuakul(D)

Correspondence: sirinapaki@nu.ac.th Faculty of Education, Naresuan University, Thailand, 99 Moo. 9 Thapo, Muang, Phitsanulok 65000, Thailand

\begin{abstract}
This article focuses on impacts of collaborative action research with a spiral process of planning, acting, observing, and reflecting that had been used as a strategy to promote teacher professional development in science education of Thailand. With the school principals' support, three primary science teachers' instructional practices are the subject of individual case studies. A range of qualitative methods and data sources including participant observations, individual and collective interviews, teacher and student artifacts were adapted to elicit evidence related to change of teaching practices and perceptions on action research activities. The case study analysis showed that collaborative action research enabled the primary science teachers to change their teaching practices within the classroom conditions. Factors that were identified as important to these changes included: 1) the primary teachers needed school leadership that powerfully attends to their professional development activities; and 2) the teachers needed a university coach to collaboratively reflect and suggest how to teach in the particular subject i.e. science. In the case of a primary teacher who, having no qualifications (i.e., certification-related teacher preparation) in science teaching, additionally needed a community of professional teachers willing to collaboratively reflect on classroom experiences for better inquiry into science teaching practices. As a means to sustain the changes in this educational context, implementing the collaborative action research while providing opportunities for parents to observe and reflect upon teachers' classroom teaching practices was also found to be important.
\end{abstract}

Keywords: Action research, Professional development, Science teachers, Primary school

\section{Introduction}

Collaborative action research has been implemented as a strategy to promote development of teacher professionalism in various school contexts (Jaipal and Figg 2011) and extensively regarded for its potential to improve science educational processes (Hine and Lavery 2014) in many countries, such as the United States of America (Mitchener and Jackson 2012), Australia (Hine and Lavery 2014) and Singapore (Hairon 2017), where schools typically have adequate educational budgets, technology, learning resources and certified teachers. In Thailand, there is need for effective professional development strategies for reforming science teaching practices at primary school level

(c) The Author(s). 2019 Open Access This article is distributed under the terms of the Creative Commons Attribution 4.0 International License (http://creativecommons.org/licenses/by/4.0/), which permits unrestricted use, distribution, and reproduction in any medium, provided you give appropriate credit to the original author(s) and the source, provide a link to the Creative Commons license, and indicate if changes were made. 
particularly in rural areas where schools often have a small student population, limited teaching and learning resources, as well as ineffectively trained teachers (Office of Commercial Services 2002). This need has been recognized as a context in which schools can enhance equity and improve the quality of science education. Therefore, this research project initiated collaborative action research in primary schools to investigate contexts of science teaching and to support teachers to improve their teaching practices in authentic classrooms. This study was conducted in a lower northern province of Thailand. The study had a goal to illustrate results from studying impacts of collaborative action research implementation for teacher professional changes as case studies. These results provide significant information for school districts and teacher organizations to facilitate professional development in science teaching.

\section{Overview of the study}

As the university researcher in science education, in a large university in lower northern Thailand, the author had established a two-year project for development of teaching profession in primary school level. The first year of the project featured periods of investigating context of many primary schools in the province. The study occurred in a time of educational reform such that the teachers and staff of many primary schools were frequently confused about the meaning of the national science curriculum standards. The teachers felt that they were being challenged to develop their own school curriculum, in part due to their belief that they did not have effective supports from the government. However, the staff of the primary schools often attempted to learn about and to improve competency of their teachers. The major way in which they pursued this improvement was through emphasis on improving teaching practices through the traditional strategy of teacher training or professional programs that focused on content-based training and workshops. As a result of this emphasis on science content, some primary science teachers perceived that science teaching required extensive knowledge of complicated concepts. For these teachers, science was hard to digest and understand. Also, the teachers came to believe that science instruction could only be accomplished with the use of complicated teaching practices. The teachers were not confident of teaching science based on their perception of the requirements in the national science curriculum. Some primary science teachers who had non-science undergraduate experience, appeared to avoid teaching in science subjects when teaching alone (Kijkuakul et al. 2008; Kijkuakul 2018).

Later in the 2nd year of the study, the research project implemented action research by the teachers as the process of professional development. The author preliminarily surveyed and visited many primary schools from the 1st year study for their commitment to participation in second year of this research project. Ultimately, there were three primary schools interested in the research project. One teacher from each of these schools volunteered to be the research participants with collaborative nurturing by their school principals and the school educational district administration. Along with that implementation, the author played the role of coach who guided and supported them to become more professional in science teaching. At this phase, the author provided necessary documents and teaching manuals including the national science curriculum standards, examples of pedagogical content knowledge, and science 
assessment and evaluation to the three science teachers, and challenged the teachers to think what they individually desired to improve in their classroom instruction. Subsequently the action research activities were initiated in order to promote changes of teaching practices.

\section{Professional development}

Professional development consists of designed programs that have a goal to support teachers to understand how to accomplish student learning goals and needs. It does this by providing opportunities for teachers to develop their content knowledge and pedagogical content knowledge that address to their students' learning in authentic classrooms (Loucks-Horsley et al. 2010). In the field of science education, the importance of professional development is connected to the highly significant role that teachers play in the development of science learning experiences for students (Grossman 1990). Yager (2005) identified the following characteristics of science teachers who understand and can lead the profession toward high quality of teaching and learning. Firstly, teachers must have understanding of the nature of the scientific and technological enterprise as well as how to deal with real world problems using scientific information. Secondly, teachers must communicate science as a way of knowing about the natural world, that science is an inquiry process. Thirdly, teachers must have an ability for making decisions, a desire to learn new theories or perspectives, e.g. new curriculum and assessment that give opportunities for students' learning achievements (Yager 2005). Also, these science teacher leaders should have the ability of thinking with reasoning and problem solving for finding appropriate teaching and learning activities immediately and critically, because they will be facing unpredictable situations in their classrooms. Teachers should have experiences and instructional practices in active learning for their own professional self-development (Akcay and Yager 2010; National Research Council 1996).

Furthermore, professional development of teachers is recognized as a form of adult learning. As such, teachers need acknowledgment of why they need to learn things as well as advantages that might result from that learning. They then can develop a deeper appreciation of learning, through direct experience and problem-solving environments (Morales 2016). However, the traditional programs of teacher professional development such as workshops, outside experts, content-based training with time limitation had been more commonly used as approaches to teacher development (Guskey and Yoon 2009). Many researchers argued that traditional programs should be substituted by new effective programs of professional development (Briscoe and Wells 2002; Howe and Stubbs 1996; Jaipal and Figg 2011; Jove 2011; Koutselini and Patsalidou 2015; Mamlok-Naaman and Eilks 2012).

To design an effective program of professional development, designers need to consider four components as follows: (a) teachers' knowledge and beliefs operating in science classrooms, that was claimed in the above description about characteristics of science teachers, and (b) context of the schools and classrooms of these teachers. The teachers have school contexts that are unique features of their professional lives and include school leadership, parents-community factors and a student-centered learning 
climate. Recognition of these factors is a large part of what is needed to accomplish professional development of teachers (National Research Council (NRC) 2011). Additionally, the designers need to pay attention to (c) issues that may affect to the program and to critically select (d) strategies that are suitable to support the teachers to learn and grow in their profession (Loucks-Horsley et al. 2010).

In the education community, action research has been widely accepted as a professional development strategy. This approach emphasizes classroom-based self-inquiry that is based on contextual imperatives of teachers and focused on individual development to promote self-reflection and evaluation (Goodnough 2001, 2016; Kemmis et al. 2014; Koutselini 2008; Koutselini and Patsalidou 2015). The strength of action research is that "teachers either define the research questions or contribute to their definition in a meaningful way. Therefore, they have ownership over the process and are committed to promoting changes in practice indicated by the findings" (Loucks-Horsley et al. 2010, p.210). Ideas from the scholarship of action research and its processes are described in the next section.

\section{Action research}

Action research was recommended in the English language by Kurt Lewin, a social psychologist, in 1940s. The process of action research has been described as a systematic process operating in a non-linear (and sometimes spiral) cycle and involving the teacher in planning, action, observation and evaluation phases of the action. A practitioner who maneuvers through the process is also a researcher. Action research has been viewed as a series of commitments, made by teachers, to observe and improve instruction as an aspect of progressive learning with an emergent practice (McTaggart 1994). There are many examples in the research literature of how researchers used action research as a tool to promote practice-based learning with teachers, for instance to improve teachers' teaching practices (Garbett 2011; Goodnough 2016; Hunzicker 2016; López-Pastor et al. 2011; Mamlok-Naaman and Eilks 2012; Morales et al. 2016), and pedagogical self-awareness (Koutselini and Patsalidou 2015; Mitchener and Jackson 2012; Wallace 2013). Also, action research is used to reform teacher assessment practices (Briscoe and Wells 2002), to build teacher mindfulness (Dorman 2015) and teacher research skills (Jove 2011). Furthermore, action research is implemented to enhance the school principals' pedagogic role to support teachers' professional development (Koutselini and Patsalidou 2015).

Nowadays, characteristics of action research can vary in its implementation. For instance, spiral cycles can be implemented to stimulate effectiveness of teacher professional development. One example of an action research spiral, called a spiral of self-reflection cycle, described by Kemmis and McTaggart in 1988, prescribed a plan for action that includes planning, acting and observing, reflecting and then re-planning. This plan powerfully focuses on self-reflection and self-inquiry and is well-recognized as a basic cycle that can potentially produce continuous improvement in teaching practice (Hairon 2017, p.2). Furthermore, action research can be collaborative in either the school cultural context or the broader public sphere to improve individual teacher work and other participant work. This type of action research is often found in work between teachers and university researchers, as 
well as other research participants such as school principals, students, parents, and outside school organizations and agencies (Kemmis et al. 2014). The degree of collaboration in action research can be increased and flexible as required to fulfill the goal of the research project (Loucks-Horsley et al. 2010). Such a claim was put forward in the scholarship of April and Bouchamma (2015) who found that a teacher community composed of teachers who were pedagogically supervised by their school principals and peers, developed a culture of mutual support and collaboration for helping the teachers themselves to develop the abilities in teaching and learning using inquiry.

Along with the above claims, Kemmis et al. (2014) described four stages of the collaborative action research cycle that support the development of teaching practices as the following five ideas. Before the stage of planning, all research participants communicate with each other to share their concerns regarding practical situations and initiate a statement about what they intend to improve. At the stage of planning, teachers in collaboration with other participants set up plans for their changes in practices and practice architectures based on their stated initial concerns. Second, the stage of acting, here the teachers modify the plan by taking account of authentic situations emerging in classrooms. The actions include saying, doing and relating with others as human social activities (Kemmis et al. 2014, p.52) and to promote better learning for their students. In parallel, the stage of observing is also conducted by other stakeholders. During this time, the teachers write what is happening and gather evidence of their actions and changes. Fourth, once the action research plan is underway, it is time for participants to reflect more deeply about products of the acting and observing. In this stage, the teachers think about anticipated and unanticipated effects, side effects and what to do next, and then share these experiences with other participants through conversations. Finally, teachers with other collaborators consider what must be changed in order to change teaching practices for improvement and what must not-and why? Then, they think about what to do for better changes in next cycle (Kemmis et al. 2014, p.109).

For this study, the four stages of collaborative action research (Kemmis et al. 2014) was flexibly implemented. The implementation was based on the context of each primary school and the needs of each science teacher to promote changes of teaching practices including saying, doing and relating with their students in their class periods and/or others who supported that changes in their schools.

\section{Methodology and methods}

This research article reports on action research as a form of professional development and employs qualitative research methodology (Creswell 2014). The purpose is to investigate impacts of a form of action research labeled "the spiral process" on the changes in teacher performance associated with professional development, i.e. changes in teaching practice. Further, this project attempts to understand how to implement the action research spiral process in Thai education contexts of primary schools. Throughout the action research spiral process, the author as the university researcher, provided mentorship that included coaching and mentoring on the improvement of teaching practices. 


\section{Participants}

Three primary grades science teachers from different schools and districts in a lower north province of Thailand participated in the research project. The individual science teachers were selected because their interest in professional development and because of the indicators of school support. This article refers to the teachers on a case-by-case basis as Sunny, Anna and Jane. These names are psuedonyms. Their backgrounds and school contexts are described in the next paragraphs.

Sunny is a female and thirty-five years old. Her educational background included a Bachelor of Education in chemistry teaching. Sunny had been an elementary science teacher for 9 years at the time the study was conducted. Her school, which this article calls School A, is in a rural mountain village. The school had provided Kindergarten to Grade $6(\mathrm{~K}-6)$ education for the village community. There were sixty students and four teachers in total at the school. Sunny's teaching assignments included being the Grade 5 to Grade 6 (G5-6) teacher and the only science teacher in the school. Because of the small number of teachers, teaching and learning in a classroom was designed to specifically fit into that school context. Each classroom teaching practice was organized for a two-grade level learning group, and Sunny had to teach about two scientific concepts in parallel. Moreover, Sunny had duty in Grade 1 to Grade 6 (G1-6) science teaching for six periods a week and G5-6 non-science teaching for twenty periods a week.

Anna is a twenty-eight years old woman and a primary grade teacher in School B. Anna had a Bachelor of Business Computer degree and less experience in science teaching. Her school was in suburban area of the lower north province and provided Kindergarten to Grade 9 (K-9) educational activities for children from the local community around the school. There were one hundred students and thirteen teachers in the school. They had Distance Learning Television (DLTV) as teaching media for every classroom study. Because School B did not have enough teachers to cover both the standard grade level classes with one science period for each grade, Anna, whose primary assignment was as the third grade teacher, needed to teach all subjects, i.e., science and non-science subjects. She taught thirty teaching periods a week including two periods of science and twenty-eight periods of non-science. In the specific context of School B, Anna had a strong community of support for science teacher development. In addition to Anna, there were also three additional senior teachers who had more than fifteen-year experiences in primary science teaching. They often supported Anna's learning of how to teach science.

Jane was forty-two years old and a science teacher in School C. Her educational background included a bachelor's degree in science teaching. Specifically, Jane had both experiences in secondary and primary science teaching, for a total of 18 years. In the function of School C, they provided K-9 education for community nearby to a Buddhist temple that located in urban area of the lower north province. The school principal promoted teaching integrated with family living, religion and the school community. The school had four hundred students and twenty teachers. Because School $\mathrm{C}$ had enough number of teachers for every grade level and subject, Jane was assigned to teach science three periods a week and non-science for sixteen periods a week, for the fourth and fifth graders. 


\section{Data collection}

\section{Implementation of action research}

The three primary science teachers were introduced to the action research spiral process during the first year of the study. Preliminary to the main study, the author had visited the individual teachers and observed what was going on in their classrooms. These visits specifically focused on issues or problems about their teaching practices and then revealed what the individual teachers would like to change within their school contexts. Later in the second year of the study, when the first spiral process of action research began, the individual teachers would 1) plan to improve their teaching practice, 2) act or implement the plan in their authentic classroom, 3) observe the results of action, and 4) reflect what should be changed next for re-planning in a subsequent spiral process. Figure 1 shows collaboration in this action research process.

During the process of action research, the individual teachers and the author had a meeting once a month. There were also classroom observations and collaborative reflections. As a coach, the author observed the classroom teaching practice with the school principal and then participated in the individual teacher's collaborative reflections. The process of action research continued for 4 months. To finish the last spiral process of the action research, a parent of a student was additionally invited to visit the classroom for observing and collectively reflecting on the teaching practice. This last activity was used to sustain changes of the teaching practices. Through this activity, it was felt that three science teachers were informally induced to promise the parent or school community that they would certainly continue to do the preferred actions, i.e. proficient teaching practices, for their children.

\section{Interview and observation as monitoring impacts of action research}

As part of the preliminary study, face-to-face interviews were conducted to communicate with the three primary science teachers about the research aims and process and to gain information on their educational background and experience in science teaching, e.g.

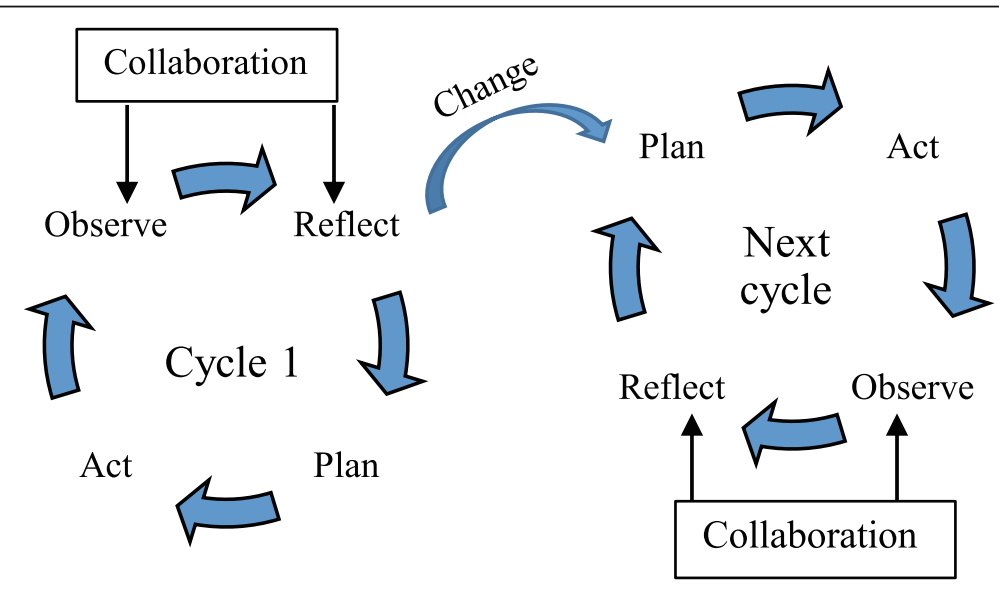

Teacher and school contexts

Fig. 1 Collaboration action research process in this study 
teaching strategies, teaching media and assessment. There were three 60-min interviews were recorded. Examples of the interview questions were: (1) Could you please tell me what teaching strategies you have used in science classrooms?; (2) Which teaching strategies you think are suitable for science study?; and (3) Why?. All teachers were not only interviewed, but also observed to confirm their interview data. Therefore, a two-hour science classroom of each teacher was additionally observed and recorded. Data of this preliminary study were collected before the implementation of action research.

For the duration of implementation of action research spiral process, this study used participant observation (Taylor et al. 2015) to collect data in the stages of acting and observing of action research. The three primary science teachers' teaching practices in the science classrooms were recorded in field notes by the author, once a month, for 4 months. Totally the observational field notes covered twelve two-hour periods of science teaching.

After the participant observation of a science class period, a 45-min conversational interview would additionally be conducted in the stage of reflecting of action research. The individual teachers, the school principal and the author would reflect collaboratively about the primary science teachers' content knowledge and pedagogy related to the national science curriculum standards. Guiding questions used for the collaborative reflections included: (1) How did you prepare the teaching activities?; (2) What do you think about your teaching today?; and (3) What would you like to improve from today's lesson?. In addtion, a few conversational interview questions were also asked such as: According to your teaching strategy, do you think that [previous] teaching is better than your teaching [today]?. These questions were created to explore the scope of issues covered within the group reflection. The conversations were audio-recorded by the author, once a month, for 4 months. In summary, this study conducted twelve 45-min conversational interviews, through the reflecting stage of action research, to investigate changes of the teaching practices and confirm the previous observational data. Finally, teacher and student-created artifacts, such as lesson plans and learning journals were used as evidence to support the reflections.

\section{Data analysis}

All observation data and interview data were transcribed. Field notes and transcriptions were read and rechecked by the individual science teachers, as member checking for trustworthiness of this study. Then content analysis of the data began with re-reading and coding to correspond to the research aims. In order to create initial codes, this study considered four components effecting to professional development (Loucks-Horsley et al. 2010; National Research Council (NRC) 2011) as follows: (1) teacher knowledge and beliefs (2) teacher context (3) issues affecting teacher development and (4) strategies supporting teacher development. As an inductive approach, categories of codes then were generated. This coding process was repeated several times. Finally, there were three main categories, i.e. scientific conception, pedagogy and conditions of professional development, emerging from the observation data and interview data. Also, document analysis of the created artifacts would be used to support the 
Table 1 Examples of categories, codes, and assertions

\begin{tabular}{|c|c|c|}
\hline Categories & Codes (Meaning) & Assertions \\
\hline \multirow[t]{2}{*}{ Scientific conception } & $\begin{array}{l}\text { SU (Sound understanding } \\
\text { in the concept) }\end{array}$ & $\begin{array}{l}\text { The air moves from this [room] temperature area to } \\
\text { another [hotter] temperature area. }\end{array}$ \\
\hline & $\begin{array}{l}\text { MU (Misunderstanding in } \\
\text { the concept) }\end{array}$ & $\begin{array}{l}\text { What was in the glass [that caused the paper to stick } \\
\text { on the glass]? It was the pressure, wasn't it? It was the } \\
\text { pressure and the pressure sucked the water, so the paper } \\
\text { wasn't falling down. }\end{array}$ \\
\hline \multirow[t]{2}{*}{ Pedagogy } & TP (Teaching planning) & $\begin{array}{l}\text { [to design a hands-on activity about air concept]...। } \\
\text { studied from the internet, the documents, and the TV. }\end{array}$ \\
\hline & $\begin{array}{l}\text { QT (Question promoting } \\
\text { thinking) }\end{array}$ & $\begin{array}{l}\text { In this experiment... where did the air come out after } \\
\text { we light the candle? } \\
\text { Can you tell me about the difference of temperature } \\
\text { between the start and the end areas of the bottle pipe? }\end{array}$ \\
\hline \multirow[t]{2}{*}{$\begin{array}{l}\text { Conditions of } \\
\text { professional } \\
\text { development }\end{array}$} & TC (Teacher context) & $\begin{array}{l}\text { I really got ideas of how to teach from the TV....also I } \\
\text { consulted the [senior] teachers if I couldn't understand } \\
\text { those resources. }\end{array}$ \\
\hline & $\begin{array}{l}\text { TA (Teacher awareness of } \\
\text { self-improvement) }\end{array}$ & $\begin{array}{l}\text { The project helped me to develop myself... I'm aware } \\
\text { of teaching preparation...variety of activities [this caused] } \\
\text { my students having better understandings in science. }\end{array}$ \\
\hline
\end{tabular}

observation and interview data, as method triangulation. Examples of codes and categories are illustrated in Table 1.

As the research aims were conducted through the implementation of action research, there are experiences on collaborative action research for changing teaching practices of three primary science teachers and its effects in contexts. The following section contains the three cases, Sunny, Anna and Jane from school A, school B and school C respectively.

\section{Results}

Implementation of the action research spiral process in primary school contexts of Thailand required two sessions of professional development prior to data collection in science teaching classrooms. Firstly, there was surveying the school contexts and science teacher backgrounds, working with teachers to help them understand how to teach science based on the national science curriculum standards, and encouraging all science teacher participants to be confident in the process of action research. Secondly, there were implementation steps of planning, acting, observing and reflecting on changes in teaching practices. Here the primary science teachers preliminarily needed the university researcher to be a leader of change. The individual science teachers would be asked to critique what the problems of teaching and learning in their classroom were and then make decisions regarding which problem they needed to examine as first priority. After each teacher made this decision, the planning step in spiral cycle 1 of action research then began. In addition to empowerment for change, the primary science teachers also needed the school principal to attend their classes to communicate to other stakeholders for adjusting school perceptions about science teaching. The author of this study was present for and involved in all of the activities described above.

Findings in this study indicated that implementing the action research spiral process for at least three cycles enabled the primary science teachers to make significant progress toward their goals of changing instruction as identified in the 
process described above. Ultimately these changes would have an even great impact during spiral cycle 4 with additional participation of parents from the school community. The following cases describe the process and results of three primary science teachers' examination of their instructional practice using action research.

\section{Sunny's changes}

Within Sunny's school context, this study found that she appeared to have more confidence in science teaching. She changed her approach to classroom management and other teaching strategies. Analysis of the data showed that Sunny was more aware of holding more complete scientists' conceptions of scientific content as well as deeper understanding of relationships between science and everyday life. Collaboration on professional development among Sunny, the author and the school principal appeared through all spiral cycles of this action research.

Cycle 1 Sunny selected to examine problems about classroom management. Within her school context she was teaching in a classroom that had been divided for two student groups i.e. the fifth graders and sixth graders. The timing of her teaching activities had previously been arranged temporarily based on grade order. The grade five students received lecturing and discussion from Sunny before the sixth graders. During her examination of problems in her classroom instruction, she decided that this tradition had been confusing for all students in whole classroom. There were 11 students in this classroom situation. She had concluded that each of her students had made noise and been uncertain about whether Sunny was speaking to them or to another. As a result of the collaboration, Sunny changed the classroom arrangement. In her subsequent teaching, both of the grade-level groups of students participated in similar activities together. Participant observation data indicated that the learning atmosphere changed so that to an observer it appeared as though there were two teams working at studying science activities. While participating in the reflection step, Sunny revealed more self-confidence in science teaching. She perceived that teaching through these instructional experimentations, the two different grade-level groups of students were enabled to achieve greater learning in science. Sunny addressed what she felt was the most important reason for the change. She said in an interview: "The experimentations provided opportunities for the students to help each other to do things collectively...here I could insert the scientific contents for their better learning". With regard to the actual instructional strategies implemented, Sunny appeared to change her teaching strategy step by step. In this cycle, her initial step of change started with acceptance that experimenting could better promote her student science learning than lecturing. Her next steps of change are described in next cycles respectively.

Cycle 2 Sunny had learned her weak points of teaching through experimentation. With group reflections in the prior cycle, Sunny had been challenged to further develop her instructional procedures to boost students' critical thinking through the instructional experimentation. She did try to provide questions to support her students' learning by launching classroom discussions before and after the hands-on activities, however, Sunny's progress was difficult because of her inappropriate questions that 
came from holding scientific misconceptions. The conversation in her classroom practice about air pressure signified that as follows:

Sunny: ...after you poured the water to fill the glass. What would you do next?

Students: [We] brought the hard paper to cover the mouth of glass and then turned it upside down.

Sunny: Did the hard paper stick on the mouth of the glass?

Students: Yes, it did.

Sunny: What was in the glass [that caused the paper to stick on the glass]? It was the pressure, wasn't it? It was the pressure and the pressure sucked the water, so the paper wasn't falling down. Therefore, what was in the glass?

Students: Pressure.

After class the author discussed with Sunny about her misconceptions about air pressure which prevented her from asking good questions for discussion with her students while summarizing the experiment. She finally came to understand from the author's scientific explanation that she had a misunderstanding about the role of air pressure. Then the author reflected with her that "You appeared to hesitate in questioning about the experiment...why?". Sunny's answer was "I felt uncertain with that concept". This situation brought Sunny to be aware of paying more attention to self-regulated learning in science conceptions. Her awareness was addressed in an interview: "I will improve my [understanding of scientific] concepts more than I ever did [before]". As her step of change through this cycle, Sunny had learned that transformation from lecture to experimentation needed her correct concepts in science, and she must remedy that by herself.

Cycle 3 progressions exhibited by Sunny suggests that she was learning a great deal during the previous cycles. "I tried to search and re-read the concepts that I wasn't clear,...I started from [analyzing] the science standards...if I didn't understand the core concept I would surf the internet...also I read the document about pedagogy that you gave me last semester", Sunny said in the conversational interview. Having gained greater self-awareness of the teaching profession, Sunny was empowered to reach a high quality of changes. Sunny considerably improved her scientific conceptions and teaching strategies for classroom discussion. One important change happened in her construction of lesson plans. As she progressed in her work of the action research, her lesson plans were increasingly designed to promote students' ability to connect scientific knowledge to their everyday life, which is based on the content of the national science curriculum. During the third cycle of the action research, no misconceptions regarding science content were found. This time her teaching practices about the topic of chemical reaction appeared to be well organized as well as scientifically accurate. Further, she was able to launch discussions for summarizing an experiment appropriately. Her successful implementation of teaching practices was additionally confirmed with students' learning tasks that she created. In the new tasks, the students could 
present their understandings and ability to apply scientific concepts, i.e. new substances and chemical reactions, and propose ways to solve environmental problems in their community. Sunny challenged the students to critique how to protect themselves from chemicals in situations where it was necessary to use those in their farms. As a result, one student proposed an idea that "when I need to use chemical substances to spray on the crop, I need to wear clothes [that] cover all parts of my body and stay upwind of the air currents otherwise the chemicals will harm me...".

Cycle 4 was directed toward establishing sustainability of the teaching professional development. Sunny was challenged by the fact that in cycle 4 , the author and the principal would invite a student's parent to observe the classroom teaching practice. However, Sunny became willing to support that invitation and at the real classroom session, Sunny appeared to teach as the way she had done in cycle 3. After class, Sunny was asked to reflect on her teaching progression and perceptions on this action research project. She claimed that the research project assisted her to develop the teaching practices and to gain understanding about how to teach science. "The project helped me to develop myself...I'm aware of teaching preparation...variety of activities [this caused] my students having better understandings in science..., and I will continue these actions...", Sunny said. Supplementary reflections by the school principal and the student's parent supported that claim. For instance, the school principal stated that: "Sunny has made significant progress...although she had not been able to construct appropriate questions in cycle 1, after our observations and reflections she improved and changed her teaching practices." The parent was also positive and pointed to one specific imporant part of the teaching. The parent stated: "Her teaching activity connected science to the community."

\section{Anna's changes}

In the case of Anna, action research had been implemented for 3rd grade students. As was true for Sunny, collaboration for professional development among Anna, the author, the school principal, or a representative sent by the principal, appeared on all spiral cycles of the action research project. Because of special circumstances of the school principal, however, he had sent a senior science teacher, as a representative from the school B professional learning community, to participate in this research project in cycles 2 to 4. Results indicated Anna's progress in terms of growing self-awareness during the stages of the professional development and more confidence in science teaching. Also, Anna improved her teaching skills specifically related to the design of science lessons based on the national science curriculum standards and she changed her teaching strategies from lecture to a focus on science practices through experimentation and discussion.

During Cycle 1, it became evident that due to her educational background as a non-science major and her work experience in business computing, Anna, the primary science teacher, from school B, was not familiar with culture and knowledge of science. She had less confidence in science teaching and usually used talk and chalk as her primary teaching strategy to develop students' scientific conceptions. Also, she often used the Distance Learning Television (DLTV) to enhance students' 
science process skills without actively engaging in that instructional activity. However, when Anna knew that her science classroom teaching practices would be observed by the author and the school principal, she changed her focus to designing a hands-on activity in the topic of "quality of water" for her students. After Anna's teaching practices were collaboratively observed and reflected upon, she became aware of how her knowledge of science and thus her teaching contained content misconceptions. At this point, the school principal suggested to her that sharing and entering into a collaboration with a senior science teacher from school B might be a productive path for improving her science teaching. The author of this study also recommended studying documents, materials and websites about how to teach science. As a result of these changes, Anna appeared to be more aware of the potential for self-professional development as a means to improve as a science teacher.

By the onset of Cycle 2 Anna's instruction had evolved from passive to active. Anna started with rearranging students' group desks so that each faced toward the blackboard in the front of the classroom rather than facing the DLTV. This new classroom desk arrangement ensured that all students would be able to see the teacher's demonstration of science labs and participate in classroom discussions more easily and conveniently. One of Anna's primary instructional interests was changing her teaching strategies to include more laboratory experimentation. During this cycle, she prepared a hands-on activity about air concepts, by studying science lessons downloaded from the website and the teaching manual of the DLTV. Alongside that study, Anna constructed her own lesson plan to guide her teaching practices in cycle 2 . The following conversational interview supported the finding that Anna's changes to her teaching practices are significant to her students' learning.

Author: Could you please explain how did you prepare the activity?

Anna: ...I studied from the internet, the documents, and the TV...I really got ideas of how to teach from the TV... also I consulted the [senior] teachers if I couldn't understand those resources.

Author: Today, were you confident to teach by yourself?

Anna: Yes, I was...I used to utilize the TV only because I had no ideas of how to teach and I didn't know much about science, [but] this time I made an effort to teach science by myself.

Author: ...Do you think that [previous] teaching by the TV is better than your teaching [today]?

Anna: No...when I had taught [by myself] the students could learn more...the TV often talked too fast. My students couldn't track their ideas of science.

This excerpt from one interview illustrates not only how Anna explained her increased confidence in science teaching but also how Anna has learned to search new sources of knowledge for improvement of self-teaching practices. These findings 
confirm that changes of the teaching practices could result from collaborative observation and reflection in action research reported in similar research studies (Kemmis et al. 2014).

However, evaluation of Anna's lesson plans in Cycle 2 by the author indicated that Anna still needed to relate her use of hands-on activities to the national science curriculum standards. The analysis also suggested a need for Anna to expand critical questions to challenge students' thinking about the experimentation. Findings from the analysis of data in the subsequent cycles indicated a continued improvement in relation to these goals.

In cycle 3 Anna taught science with both experimentation and discussion. The hands-on activities about the properties of materials, i.e. wood, metal and fabric, were managed properly, and the lesson plan was organized taking the national science curriculum standards into account. In addition, Anna raised critical questions to draw the students' ideas in science activity.

In cycle 4, Anna then was challenged to exemplify teaching in science for the school community. As with the other teachers, one student's parent was invited to observe and reflect on the teaching and learning in the classroom. During this fourth cycle, Anna illustrated how she had sustained her new teaching practices through experimentation (see Fig. 2) and discussion as well as she had done in cycle 3. This is shown by a discussion between Anna and the students about temperature and air movement in a third grade classroom. Consider the following example:

Anna: What do you think? Can the air move? Why?

Students: It can move.

Anna: How do you know it moves?

Students: ...when I made a fire, the air would let it burn and moved with the wind...

Anna: In this experiment...where did the air come out after we light the candle?

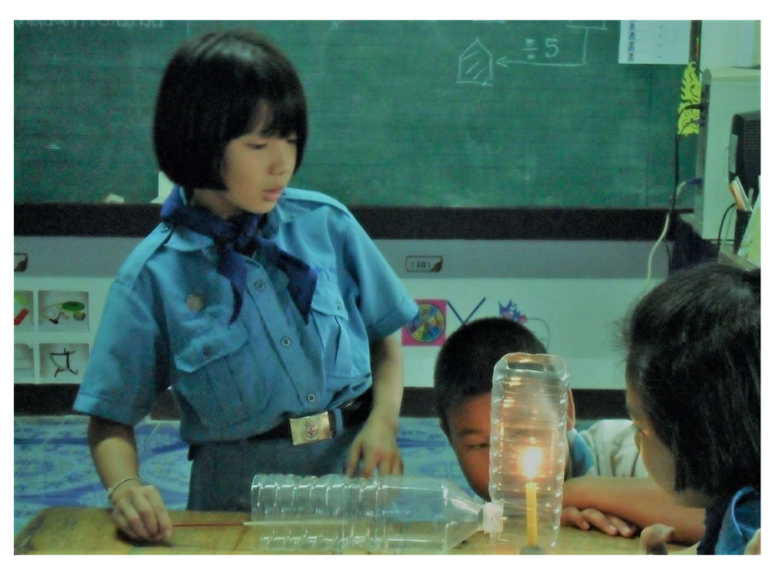

Fig. 2 The experimentation of air movement. The students were observing and explaining about the direction of air movement 
Students: The air would move to the candle and come out from the bottle.

Anna: How did you observe movement of the air?

Students: ...observed smoke of the incense stick burned.

Anna: Can you tell me about the difference of temperature between the start and the end areas of the bottle pipe?

Students: The end area is hotter than the start area.

Anna: So, what is the direction of air movement...[based on the temperature]?

Students: The air moves from this [room] temperature area to another [hotter] temperature area.

\section{Jane's changes}

Jane was a new science teacher in the School C, but even with her qualifications in science teaching and extensive teaching experience at primary and secondary science levels, Jane was not anxious to participate in this action research project. Because the school principal was very busy in that time, he recommended a senior teacher to observe and reflect Jane's teaching practices instead. Collaboration on the spiral process of action research was inconsistent. Changes of Jane teaching practices appeared in positive way only in cycles 1 and 2 and needed to be stopped in cycle 3.

During Cycle 1 Jane appeared to teach science by experimentation with high confidence, but examination of data from the observations indicated that her students did not accomplish effective learning. Jane conducted science experiments based on a teacher-centered approach. Her instruction was drawn directly from the textbook and consisted of explaining all steps of inquiry, without challenging students to think about what and why they were doing them. Also, the students were expected to follow her spoken directions. As a result, the classroom control was lost. There was a lot of noise; students walked around the classroom and asked each other how to do the experiment across the teaching period, but the students could not understand what was required to complete the lab assignment. After the inital observations, ideas about teaching science based on a student-centered approach, classroom management and linking science activities into the national science curriculum standards rather than the textbook were negotiated by Jane and the author. A re-planning was conducted for this content, but no reflections from the senior teacher were contributed throughout the implementation of action research.

In the second cycle, Jane changed her classroom physical setting in a manner that seemed to promote more student-centered instruction. She led students to form desks into a group formation where they could discuss and observe science experiments easier. But even with these changes, Jane then performed experimentation based on teacher-centered approach. Without discussion and interaction to help them to note the processes of experimentation, the students still could not describe what they 
learned on the lab assignment. The following reflections indicated that Jane also acknowledged the students rarely had learning effective.

Author: What do you think about your teaching today?

Jane: ...not well because I focused on teacher-centered approach. I used only the lab direction...and the students couldn't work on them...they copied each other and didn't know what they need to do. I had to explain again and again.

Author: What would you like to improve for today?

Jane: ...teaching process...because they had not been familiar with group work...so they didn't know what to do. I need to train them more and more.

This action research event ended with the Cycle 3 during which Jane performed a well-organized teaching activity. Improvement in her strategy on experimentation appeared to be related to her belief in the importance of more focus on student-centered instructional approaches. Jane clearly demonstrated how to use the lab instruments and guide students to do the experiment step by step. She asked and waited for students' answers. This time the students responded to Jane's questions about the experiment by answering and writing their ideas on the lab assignment. These confirmed that students could follow her description of the laboratory experimentation. Nevertheless, what Jane thought about her changes is quite negative. "It is very difficult for me to plan a set of [hands-on] activities like this, ...this is extra workload, I spent too much time for today. I don't want to improve anything. This semester, the school [principal] has provided me extra works to do. I have no time", Jane said.

\section{Conclusions}

After the implementation of four spiral cycles of collaborative action research within the three primary school contexts, the individual teachers illustrated changes as categories within the following themes.

\section{Teacher scientific conceptions were needed as a priority of and for change}

In the case of Sunny, as a result of holding misconceptions in science, the teacher could not produce appropriate questions for student learning in hands-on activities, such as the experimentation about air pressure in cycle 2, and felt uncertain with the misconception that negatively affected to the changes of her teaching practices. The teacher came to perceive, because of her collaborative reflection, that she paid more attention to her own self-regulated learning of science conceptions. This realization led her to also understand more clearly how she could inquire into the content knowledge from the curriculum standards and internet to develop her understanding in the science concepts. These insights enabled her planning of a new lesson in cycle 3 and designing variety of activities for her students' better learning in primary science in the next cycle. Therefore, it can be said that having appropriate scientific conceptions served as a major support for teacher self-confidence to teach in primary science. Also, the teachers used that as raw materials to design effective hands-on/minds-on activities 
based on the curriculum standards. Additionally, these findings indicated that process of collaborative action research encourages openness to awareness on self-regulated learning in professional development (Koutselini and Patsalidou 2015; Mitchener and Jackson 2012; Wallace 2013).

\section{The teacher committed to improve pedagogy in science although having non-science} educational backgrounds

In the case of Anna, the teacher who had a degree in Business Computer and less experience in teaching and often left her students with the DLTV during the science periods, was panicked about her misconceptions while summarizing the concepts related to quality of water, in cycle 1 . However, Anna accepted that at the stage of collaborative reflection. The school principal thus recommended the senior science teacher as a teaching counselor to Anna. After the reflection, Anna illustrated her attempts to change the teaching planning and strategies from passive to more active style by studying content knowledge and pedagogical knowledge from the website, the DLTV and the senior teacher. As her growth in teaching practices, she could construct her own lessons in particular the science experimentations in the next cycles.

In the circumstances of Anna, analysis of the observation and interview data strongly supported that the school principal was an important person who affected teacher professional development in positive way. This finding is very much in keeping with research results reported elsewhere (Loucks-Horsley et al. 2010). Moreover, the findings also support the claim that an exchange of ideas or information between junior teachers and senior teachers could promote development of teaching practices in schools. This form of collaboration is a means to create a community of science teachers (April and Bouchamma 2015), in particular when the teachers have non-science educational backgrounds.

\section{School leadership participation in action research was the successful condition of professional development}

In this study, all school principals were invited to participate collaboratively in the stages of observing and reflecting in the action research, but Jane's school principal was very busy and could not participate in the stages, so he commended the senior science teacher to do that instead. In the case of Jane, although she was the teacher who did qualify in science teaching and tried to change her teaching practices, she could not continue her professional development. As evidences illustrated in cycles 2 and 3 that she exhibited self-regulated learning, and she understood what her weak point was and what she need to improve. And she was able to gradually walk across her common perception of good teaching from teacher-centered to student-centered approach. However, with the school context which was highlighted by the lack of school leadership participation in the action research, Jane was finally not confident to continue changes in the teaching practices (April and Bouchamma 2015; Koutselini and Patsalidou 2015; National Research Council (NRC) 2011). In constrast, in case of Sunny, the school principal recognized the significant progress of Sunny from cycle 1 to cycle 4. This recognition played an important role in her beliefs about her professional growth. At this point, it can 
be said that the school principal's participation is a key factor of professional development in primary science teaching.

\section{Continuity of collaboration in the stages of observation and reflection enabled sustainability of changes}

In this study, collaborations among the primary science teachers, the school principals and the author were conducted in all cycles, and the parents additionally participated in the last cycle. Roles taken on by the author included coaching and supporting all teachers with learning materials. The author, the school principals, and the parents also played roles as participant observers and participants in reflection. These collaborations occurred across 4 months to promote the changes in practices. Also, Sunny accepted in cycle 4 that continuity of this action research project helped her to develop herself and she would continue her changes. These findings support our belief that collaborative reflection while implementing action research generated an increased sense of professionalism in education (Goodnough 2016; Hunzicker 2016; and Morales et al. 2016).

Moreover, Anna reflected that "continuing observation in the action research project enabled her to construct better teaching in science and to link lessons into the national science curriculum standards." All findings in Anna's case are consistent with scholarship related to action research and as such supports the finding that teaching can be strongly influenced by the context and the community (Koutselini and Patsalidou 2015). In particular, the presence of a university researcher and a student's parent provides support for change of teaching practices that might not happen by a teacher in the absence of these supports (National Research Council (NRC) 2011).

\section{Discussions and implications}

In Thailand, there are a wide variety of primary school contexts in the lower northern areas. As is shown in this research, primary teachers with either science teaching or non-science background are playing roles as science teachers in primary schools. Findings from the three cases studies, described in this project, show that challenging primary science teachers through implementation of action research as a spiral process could be successful to improve teaching practices in authentic classrooms. However, it was clear that this action research needed strong collaboration among the individual science teachers, the school principals, the university researcher and the parents from the community.

At the beginning steps of change, all science teachers felt tensions related to their performance as science teachers and little confidence in self-teaching practices in science. These teachers needed help and encouragement from the university expert, who reflected and sought to inspire them to be aware of self-regulated learning, in particular change of misconceptions and pedagogy. When implementing the action research spiral processes in order to put in place changes related to their teaching goals, they also needed support and attention from their school principal. Whenever the spiral process of collaborative action research enabled the science teachers to perceive weakness in their instructional approaches, such as too much reliance on traditional teaching strategies, then increased self-awareness was judged to be a product of the professional development. When this happened, the science teachers' instructional approaches were 
noted to have high quality changes. This level of change was observed in the cases of Sunny and Anna.

This research study also found that whether science teachers had a background in either science or non-science, they could develop their ability of teaching in primary science. This was observed most deeply in the case of non-science background teacher, Anna. As the professional development progressed, Anna was found to have benefited not only from the collaborative observation and reflection in action research, but also showed gains from input received from her science teacher community in her school. All of these factors, strongly supported Anna to have a respectable manner in science teaching. This was the opposite of Jane's situation. She had high experience in science teaching but lacked the school principal support. This caused her lack of inspiration to continue developing new approaches to science teaching.

This research has also demonstrated that sustaining high quality change is supported by inviting parents of students to observe and reflect on teaching practices. In this way, the parents played an important role as representatives of the school's community to energize the science teachers (i.e. Sunny and Anna) to continue implementing new ideas of teaching science into their classroom practices. Participation of the parents also helped the science teachers to appreciate participating in spiral process of collaborative action research. Having these individuals present and engaged gave the teachers a chance to improve and illustrate their better teaching in science classroom and then to receive compliments from their school's community stakeholders.

The results of this implementation of collaborative action research emerging from this research report can be used by school administrators and professional organizations to facilitate professional development to minimize gaps between quality of science teaching in primary school in rural and urban areas. To succeed in the implementation, university faculty who are providing professional development need to act like coaches who induce teacher confidence in science teaching and awareness on self-development. Moreover, school administrators need to devote time to participate in at least three spiral cycles of collaborative action research especially for novice science teachers. In cases where the school has a strong profession learning community in science teaching, the school administrators can use that to support for professional growth of the novice science teachers in parallel, by allowing senior science teachers to join in the spiral cycles. Involvement of these senior teachers can also allow the school administrators to move into the background across the cycles of action resesarch.

Considerations of internationally implementation of the results of this research study for other Asian countries, such as Australia (Stamopoulos 2015), the Philippines (Morales 2016) and Singapore (Hairon 2017), an appropriate model of action research in those locations would be the first requirement. This model would be used to support teachers to focus on ongoing self-regulated learning through reflective practice and to sustain the action research model within that country's teacher development. Given the acquisition of an appropriate model, the author's experience suggests that the collaborative action research model (Fig. 1) would promote collaborations among teachers, university faculty, school administrators and students' parents for the purpose of improving primary grade instruction in science. In the adopted model of action research, stages of observation and reflection would need to be a significant component. 
As the first indication of success, this study highlights the importance of eliminating misconceptions in content knowledge, and in this particular case, of science teachers (Gillies and Nichols 2015). In addition other implementations of a model of this type must provide adequate support for the teachers to improve their pedagogical knowledge. One outcome of the school administrators' collective participation in the action research model was that teachers feel concern about holding misconceptions while they are teaching in front of participant observers. These concerns are a force that seems to cause them to begin to be aware of self-regulated learning to improve the conceptions and teaching strategies. Also, their participation led the school administrators to understand the real classroom situation and problems encountered by the teachers in those classes (Hilton et al. 2015; Wang 2016). The resulting awareness induced the school administrators to re-consider and facilitate up-to-date and various forms of teaching support, (e.g. senior-teacher mentor, the internet, attention to teacher workload and time constraints) as a means to continue support of their teachers' teaching practices.

As another task to sustain teachers' implementation of the action research spiral process in teacher professional development, this study examined way to encourage an additional collaboration of students' parents in the stages of observation and reflection. Research has suggested that in Singapore, the majority of teachers have not been convinced to prioritize professional learning as a responsibility for their teaching life due to great emphasis placed on grading assignments and "giving" student the subject matter content (Hairon 2017). Engaging in an action research approach might be a way to convince those teachers of the importance of professional growth. In particular, this study suggests that the parents' participation should be promoted to inspire and maintain teachers' interest in the sustained implementation improved practice resulting from professional development.

The success of science education reforms is often determined by the quality of teacher practices in schools. Qualified and skilled teachers are agents of change and raise the quality of science education. Through this research project, it is hoped that new perspectives on professional development and the potential power of action research to contribute to the theoretical and practical background found in this research literature will serve as a means to promote teachers' professional change.

Abbreviations

DLTV: Distance Learning Television; K-6: Kindergarten to Grade 6; K-9: Kindergarten to Grade 9; NRC: National Research Council; TV: Television; G1-6: Grade 1 to Grade 6; G5-6: Grade 5 to Grade 6

\section{Acknowledgements}

This study (MRG5480020) was supported by the Thailand Research Fund (TRF). Also the author thanks Naresuan University for giving all facilitations for teacher professional development and all research participants who collaboratively worked for the progress of science education. Finally, the author would like to thank Professor J. Steve Oliver who encouraged and helped me to complete this manuscript.

Funding

This study was supported by a grant from the Thailand Research Fund (TRF) and Naresuan University, under the project number MRG5480020.

\section{Availability of data and materials}

This study was approved for ethics clearance by the Thailand Research Fund (TRF). All research participants provided informed agreement at the beginning of the study. 


\section{Competing interests}

The author declares that he/she has no competing interests.

\section{Publisher's Note}

Springer Nature remains neutral with regard to jurisdictional claims in published maps and institutional affiliations.

Received: 7 September 2018 Accepted: 8 January 2019

Published online: 21 January 2019

\section{References}

Akcay, H., \& Yager, R. (2010). Accomplishing the vision for teacher education programs advocated in the national science education standards. Journal of Science Teacher Education, 21(6), 643-664.

April, D., \& Bouchamma, Y. (2015). Teacher supervision practices and principals' characteristics. Alberta Journal of Educational Research, 61, 329-346.

Briscoe, C., \& Wells, E. (2002). Reforming primary science assessment practices: A case study of one teacher's professional development through action research. Science Education, 86(3), 417-435.

Creswell, J. W. (2014). Educational Research: Planning, Conducting and Evaluating Quantitative and Qualitative Research, $4^{\text {th }}$ Ed. U.K.: Pearson.

Dorman, E. (2015). Building teachers' social-emotional competence through mindfulness practices. Curriculum and Teaching Dialogue, 17(1), 103-119.

Garbett, D. (2011). Developing pedagogical practices to enhance confidence and competence in science teacher education. Journal of Science Teacher Education, 22(8), 729-743.

Gillies, R. M., \& Nichols, K. (2015). How to support primary teachers' implementation of inquiry: Teachers' reflections on teaching cooperative inquiry-based science. Research in Science Education, 45(2), 171-191.

Goodnough, K. (2001). Teacher development through action research. Action in Teacher Education, 23(1), 37-46.

Goodnough, K. (2016). Professional learning of K-6 teachers in science through collaborative action research: An activity theory analysis. Journal of Science Teacher Education, 27, 747-767.

Grossman, P. L. (1990). The making of a teacher: Teacher knowledge and teacher education. New York: Teachers College Press.

Guskey, T. R., \& Yoon, K. S. (2009). What works in professional development? Phi Delta Kappan, 90(7), 495-500.

Hairon, S. (2017). Action research in Singapore: Where are we now? Asia-Pacific Science Education, 3(5, 1), -18

Hilton, A., Hilton, G., Dole, S., \& Goos, M. (2015). School leaders as participants in teachers' professional development: The impact on teachers' and school leaders' professional growth. Australian Journal of Teacher Education, 40(12), 104-125.

Hine, G. S. C., \& Lavery, S. D. (2014). Action research: Informing professional practice within schools. Issues in Educational Research, 24(2), 162-173.

Howe, C., \& Stubbs, H. S. (1996). Empowering science teachers: A model for professional development. Journal of Science Teacher Education, 8(3), 167-182

Hunzicker, J. (2016). Scholarly teaching through action research: A narrative of one professor's process. InSight: A Journal of Scholarly Teaching, 11, 15-28.

Jaipal, K., \& Figg, C. (2011). Collaborative action research approaches promoting professional development for elementary school teachers. Educational Action Research, 19(1), 59-72.

Jove, G. (2011). How do I improve what I am doing as a teacher, teacher educator and action-researcher through reflection? A learning walk from Lleida to Winchester and back again. Educational Action Research, 19(3), 261-278.

Kemmis, S., McTaggart, R., \& Nixon, R. (2014). The action research planner: Doing critical participatory action research. Singapore: Springer.

Kijkuakul, S. (2018). Teachers' perceptions on primary science teaching. [Abstract]. AlP Conference Proceedings, 1923, 030027 Retrieved from https://doi.org/10.1063/1.5019518.

Kijkuakul, S., Yutakom, N., Roadrangka, V., Engkagul, A., Barker, M., \& Eames, C. (2008). Teacher tensions when adopting a new approach to teaching about photosynthesis. Journal of Science and Mathematics Education in Southeast Asia, 31, 65-78.

Koutselini, M. (2008). Participatory teacher development at schools: Processes and issues. Action Research, 6(1), 29-48.

Koutselini, M., \& Patsalidou, F. (2015). Engaging school teachers and school principals in an action research in-service development as a means of pedagogical self-awareness. Educational Action Research, 23(2), 124-139.

López-Pastor, V. M., Monjas, R., \& Manrique, J. C. (2011). Fifteen years of action research as professional development: Seeking more collaborative, useful and democratic systems for teachers. Education Action Research, 20(2), 153-170.

Loucks-Horsley, S., Stiles, K. E., Mundry, S., \& Hewson, P. W. (2010). Designing professional development for teachers of science and mathematics (3rd ed.). California: Corwin Press.

Mamlok-Naaman, R., \& Eilks, I. (2012). Different types of action research to promote chemistry teachers' professional development - A joined theoretical reflection on two cases from Israel and Germany. International Journal of Science and Mathematics Education, 10(3), 581-610.

McTaggart, R. (1994). Participatory action research: Issues in theory and practice. Educational Action Research, 2(3), 313-337.

Mitchener, C. P., \& Jackson, W. M. (2012). Learning from action research about science teacher preparation. Journal of Science and Teacher Education, 23(1), 45-64.

Morales, M. P. E. (2016). Participatory action research (PAR) cum action research (AR) in teacher professional development: A literature review. International Journal of Research in Education and Science (IJRES), 2(1), 156-165.

Morales, M. P. E., Abulon, E. L. R., Roxas-Soriano, P., David, A. P., Hermosisima, V. H., \& Gerundio, M. (2016). Examining teachers' conception of and needs on action research. Issues in Educational Research, 26(3), 464-489.

National Research Council (NRC). (1996). National Science Education Standards. Washington, DC: National Academic Press.

National Research Council (NRC). (2011). Successful STEM education: A workshop summary. a. Beatty, rapporteur. Committee on highly successful schools or programs for K-12 STEM education, board on science education and board on testing and assessment. In Division of behavioral and social sciences and education. Washington, DC: The National Academies Press. 
Office of Commercial Service. (2002). Teacher development for quality learning: The Thailand education reform project. Australia: Office of Commercial Service.

Stamopoulos, E. (2015). The professional leadership and action research training model: Supporting early childhood leadership. Australasian Journal of Early Childhood, 40(4), 39-48.

Taylor, S. J., Bogdan, R., \& DeVault, M. L. (2015). Introduction to qualitative research methods: A guidebook and resource (4th ed.). USA: John Wiley \& Sons.

Wallace, C. S. (2013). Promoting shifts in preservice science teachers' thinking through teaching and action research in informal science settings. Journal of Science and Teacher Education, 24(5), 811-832.

Wang, T. (2016). School leadership and professional learning community: Case study of two senior high schools in Northeast China. Asia Pacific Journal of Education, 36(2), 202-216

Yager, R. (2005). Accomplishing the vision for professional development of teachers advocated in the national science education standards. Journal of Science Teacher Education, 16(2), 95-102.

Submit your manuscript to a SpringerOpen ${ }^{\circ}$ journal and benefit from:

- Convenient online submission

- Rigorous peer review

- Open access: articles freely available online

High visibility within the field

- Retaining the copyright to your article

Submit your next manuscript at $\boldsymbol{\nabla}$ springeropen.com 